\title{
Evaluation of Yeast Potential in the Biological Control of Colletotrichum orbiculare in Cucumber
}

\author{
Renata F. Barabasz ${ }^{1}$, Rayssa H. da Silva ${ }^{1}$, Monica C. Sustakowski ${ }^{1}$, Odair J. Kuhn ${ }^{1}$, Jeferson C. Carvalho ${ }^{1}$, \\ Juliano Zimmermann ${ }^{1}$, Willian dos Reis ${ }^{1}$, José R. Stangarlin ${ }^{1} \&$ Poliana S. Zimmermann ${ }^{1}$ \\ ${ }^{1}$ Agricultural Science Center, State University of Western Paraná, Marechal Cândido Rondon, Paraná, Brazil \\ Correspondence: Renata F. Barabasz, Agricultural Science Center, State University of Western Paraná, PR, \\ 85960-000, Brazil. Tel: 55-45-98804-5757. E-mail: renatafiller.b@gmail.com
}

Received: August 2, 2020

doi:10.5539/jas.v12n10p295
Accepted: September 1, $2020 \quad$ Online Published: September 15, 2020

URL: https://doi.org/10.5539/jas.v12n10p295

This research was financed import by the Coordination for the Improvement of Higher Education Personnel (CAPES) with the Finance Code 001.

\begin{abstract}
This work aimed to evaluate the effect of the yeasts Candida albicans, Pichia guilliermondii, Rhodotorula glutinis, Saccharomyces cerevisiae and Zygoascus hellenicus in the control of anthracnose in cucumbers. The influence of volatile and non-volatile compounds on mycelial growth and the effect of cell suspension and culture filtrate on conidial germination were evaluated. In a greenhouse, yeasts were tested on cucumber cotyledons, one cotyledon being treated and the other not; afterwards both cotyledons were challenged with $C$. orbiculare. The severity of the disease in both cotyledons was assessed by determining biological control and resistance induction. The production of volatile compounds from the yeasts $R$. glutinis and $C$. albicans reduced the pathogen growth by 90.7 and $90.0 \%$, respectively. The production of non-volatile compounds stimulated the pathogen development. Conidia germination was affected when exposed to cell suspension of all tested isolates, ranging from 43 to $75 \%$. For the culture filtrate from $Z$. hellenicus, it reduced the conidia germination by $11.4 \%$. In the in vivo test, on the treated cotyledon, the yeasts $Z$. hellenicus, R. glutinis and S. cerevisiae reduced the anthracnose severity by $52.5,50.0$ and $42.5 \%$, respectively.
\end{abstract}

Keywords: antagonism, anthracnose, Cucumis sativus, resistance induction

\section{Introduction}

Cucumber (Cucumis sativus L.) is an annual crop belonging to the Curcubitaceae family of great economic expression; China has been the country with the largest cucumber production in the world, reaching approximately 56.3 million tons (Filgueira, 2008). The importance of its phytosanitary quality makes it necessary to use chemical products in order to increase yields by improving plant health (Trybom, 2010; FAO, 2018).

Anthracnose, caused by the fungus Colletotrichum orbiculare, is one of the main diseases that cause damage to the cucumber culture. The control of this disease is carried out with the use of fungicides. However, the use of these products has toxicity to the environment, residual effects and promotes the resistance of fungi to fungicides. Therefore, it is necessary to develop alternative management methods, such as biological control with the use of microorganisms and natural products with antimicrobial activity (Schwan-Estrada et al., 2003).

Therefore, the objective of this work was to evaluate the effect of the yeasts Candida albicans, Pichia guilliermondii, Rhodotorula glutinis, Saccharomyces cerevisiae and Zygoascus hellenicus on Colletotrichum orbiculare in the control of anthracnose in cucumber.

\section{Materials and Methods}

The in vitro experiment was conducted in a laboratory with a completely randomized design (CRD), containing six treatments (five yeasts and one control) with four replications. The in vivo experiment was conducted in a greenhouse with CRD containing six treatments (five yeasts and one control). 
The pathogen C. orbiculare was obtained through the indirect isolation method (Alfenas et al., 2016). The tested yeasts Candida albicans, Pichia guilliermondii, Rhodotorula glutinis, Saccharomyces cerevisiae and Zygoascus hellenicus, were obtained from the collection belonging to the Phytopathology Laboratory of the University.

\subsection{Production of Volatile and Non-volatile Antimicrobial Compounds by Yeast}

The evaluation of the production of volatile and non-volatile compounds by yeasts followed the method proposed by Romeiro (2007). During the incubation period, the fungus growth diameter was measured daily by determining two diametrically opposite measures.

After determining the mean diameter, the mycelial growth curve was elaborated and the area below the mycelial growth curve (AACCM) adapted from Shaner and Finney (1977) (Equation 1).

$$
\mathrm{AACCM}=\sum_{\mathrm{i}=1}^{\mathrm{n}}\left[\frac{\left(\mathrm{Y}_{\mathrm{i}+\mathrm{n} 1}+\mathrm{Y}_{\mathrm{i}}\right)}{2}\right]\left[\mathrm{X}_{\mathrm{i}+1}-\mathrm{X}_{\mathrm{i}}\right]
$$

Where, $Y_{i}$ : mycelium severity (per unit) in each observation; $X_{i}$ : the time (days) of each observation; $n$ : total number of observations.

\subsection{Germination of Colletotrichum orbiculare Conidia Treated With Yeast Cells or Filtrate}

To verify the effect on conidia germination, two tests were conducted using yeast cells or culture filtrate from the isolates. For this purpose, optical microscope slides containing $1 \%$ agar-water medium were used, where $30 \mu \mathrm{L}$ of the pathogen's conidia suspension was deposited in the Neubauer chamber by $1 \times 10^{6}$ conidia $\mathrm{mL}^{-1}$. For the first experiment, $30 \mu \mathrm{L}$ of cells suspension was deposited for the first assay with concentration adjusted in the Neubauer chamber by $1 \times 10^{8}$ cells $\mathrm{mL}^{-1}$, subsequently, for the second experiment, $30 \mu \mathrm{L}$ of filtrate from isolates of $C$. albicans, $P$. guilliermondii, $R$. glutinis, $S$. cerevisiae and Z. hellenicus.

The slides were placed in a gerbox containing filter paper soaked in water at the bottom and kept at room temperature for $12 \mathrm{~h}$, after which blue cotton wool of lactophenol was added to stop the growth of germ tube and paint the fungal structures. Counting up to 100 conidia in a light microscope in sequence. Germinated conidia was considered to be one whose germinal tube was twice its size.

\subsection{Bioassay With Cucumber Plants}

For the preparation of in vivo test, the cultivar Pioneiro hybrid was used, sown in a tray containing commercial substrate. The five yeast isolates were tested against the $C$. orbiculare. The treatments were applied to only one of the cotyledons of each plant, so that it was possible to observe the occurrence of resistance induction by yeast in the untreated cotyledon.

When the cotyledons were approximately $3 \mathrm{~cm}$ long, at the end of afternoon, yeast cells were suspended in a concentration of $1 \times 10^{8}$ cells $\mathrm{mL}^{-1}$. After two days, the suspension containing the pathogen conidia was applied at $1 \times 10^{6}$ conidia $\mathrm{mL}^{-1}$, on the surface of the cotyledons and kept in a humid chamber.

When cotyledons showed symptoms of the disease, they were collected separately, placed on a white surface next to a graduated ruler to be photographed. With the aid of the QUANT program (Vale et al., 2003), the healthy and sick leaf area of the cotyledons was quantified to determine the percentage of injured leaf area.

\subsection{Statistical Analysis}

The statistical analysis of in vitro and in vivo experiments were performed with the aid of the SISVAR software (Ferreira, 2011). Analysis of variance was performed and when significant the averages were compared using the Tukey test, at the level of $5 \%$ probability of error.

\section{Results and Discussion}

\subsection{Production of Volatile and Non-volatile Antimicrobial Compounds by Yeasts and in vitro Germination of Conidia}

Regarding the production of volatile antimicrobial compounds, the yeasts $R$. glutinis and $C$. albicans demonstrated greater efficiency in reducing the fungus growth, reducing by 90.70 and $90.01 \%$, respectively, followed by $Z$. hellenicus and S. cerevisiae with reduction of fungus growth by 69.07 and $61.78 \%$, respectively. On the other hand, the volatile compounds produced by $P$. guilliermondii, did not significantly interfere in the growth of C. orbiculare (Table 1).

Considering these results, it is possible to verify that these yeasts produced volatile compounds and have the potential to reduce the development of $C$. orbiculare, however, at differential levels, depending on the species, ranging from 61.78 to a reduction of $90.70 \%$. Thus, these yeasts have the potential to control organisms of agronomic importance through the production of volatile organic compounds. 
Table 1. Area under the mycelial growth curve (AACCM), number of spores present and percentage of growth inhibition for the fungus Colletotrichum orbiculare due to the production of volatile compounds (CV) and non-volatile compounds (CNV) from different yeasts

\begin{tabular}{|c|c|c|c|c|c|c|}
\hline \multirow{2}{*}{ Yeasts } & \multirow{2}{*}{$\mathrm{AACCM}(\mathrm{CV})$} & \multirow{2}{*}{$\mathrm{AACCM}(\mathrm{CNV})$} & \multicolumn{2}{|c|}{ Number of spores } & \multicolumn{2}{|c|}{ Growth inhibition $(\%)^{1}$} \\
\hline & & & $\mathrm{CV}$ & $\mathrm{CNV}\left(\times 10^{5}\right)$ & $\mathrm{CV}$ & $\mathrm{CNV}$ \\
\hline Rhodotorula glutinis & $3.36 \mathrm{a}$ & $28.50 \mathrm{ab}$ & 0 & $8.462 \mathrm{c}$ & 90.70 & -35.71 \\
\hline Candida albicans & $3.61 \mathrm{a}$ & $28.75 \mathrm{ab}$ & 0 & $0.156 \mathrm{a}$ & 90.01 & -36.90 \\
\hline Zygoascus hellenicus & $11.17 \mathrm{ab}$ & $32.50 \mathrm{ab}$ & 0 & $0.306 \mathrm{a}$ & 69.07 & -54.76 \\
\hline Saccharomyces cerevisiae & $13.21 \mathrm{ab}$ & $32.75 \mathrm{~b}$ & 0 & $2.231 \mathrm{~b}$ & 61.78 & -55.95 \\
\hline Pichia guilliermondii & $20.60 \mathrm{bc}$ & $34.50 \mathrm{~b}$ & 0 & $0.256 \mathrm{a}$ & 42.99 & -64.29 \\
\hline Control & $36.13 \mathrm{c}$ & $21.00 \mathrm{a}$ & 0 & $0.075 \mathrm{a}$ & - & - \\
\hline Average & 14.68 & 29.67 & - & $1.91^{-1}$ & - & - \\
\hline $\mathrm{CV} \%$ & 22.72 & 16.69 & - & 21.29 & - & - \\
\hline
\end{tabular}

Note. CV: coefficient of variation. Averages followed by the same letter in the column do not differ statistically from each other by the Tukey test at the level of $5 \% .{ }^{1}$ Negative values indicate growth stimulus.

França et al. (2015), observed in a similar work that the yeast $R$. glutinis showed efficacy in the postharvest control of anthracnose in pepper, caused by Colletotrichum sp. According to Silva et al. (2014), among the treatments based on use of antagonists, the yeast $R$. glutinis also revealed a significant result in relation to the control of sweet rot of pepper. In studies on the production of volatile antimicrobial compounds, Fialho et al. (2010) found that $S$. cerevisiae also has the ability to produce volatile organic antimicrobial compounds, consisting mainly of alcohols.

For the test of non-volatile compounds the tested yeasts do not reduce the fungus development, on the contrary, they induced mycelial growth, this may have occurred because the yeast filtrate created a favorable environment for its development, possibly providing nutrients for the pathogen. It is possible to see that in addition to inducing the fungus growth, it was also induced to sporulation, in which R. glutinis had the largest amount of spores present, followed by S. cerevisiae, which presented spore production greater than the other yeasts and control.

Therefore, it can be determined that yeasts that produce volatile compounds are able to reduce the development of the pathogen $C$. orbiculare in in vitro tests, being considered as conducive to biological control.

The results regarding the conidia germination test treated with cells and yeast filtrate can be seen in Table 2 .

Table 2. Percentage of germination and reduction in the germination of Colletotrichum orbiculare conidia submitted to spore germination tests with filtrate and cell suspension of different yeasts

\begin{tabular}{llllll}
\hline \multirow{2}{*}{ Yeasts } & \multicolumn{2}{c}{ Germination of conidia (\%) } & & \multicolumn{2}{c}{ Reduction (\%) } \\
\cline { 2 - 3 } \cline { 5 - 6 } & Cells & Filtered & & Cells & Filtered \\
\hline Pichia guilliermondii & $33.75 \mathrm{ab}$ & $90.00 \mathrm{ab}$ & & 62.91 & 4.51 \\
Zygoascus hellenicus & $39.75 \mathrm{~b}$ & $83.50 \mathrm{a}$ & & 56.32 & 11.41 \\
Saccharomyces cerevisiae & $34.75 \mathrm{ab}$ & $87.25 \mathrm{ab}$ & & 61.81 & 7.43 \\
Rhodotorula glutinis & $22.75 \mathrm{a}$ & $93.25 \mathrm{~b}$ & & 75.00 & 1.06 \\
Candida albicans & $31.50 \mathrm{ab}$ & $88.75 \mathrm{ab}$ & & 67.38 & 5.84 \\
Control & $91.00 \mathrm{c}$ & $94.25 \mathrm{~b}$ & & - & - \\
Average & 42.25 & 89.50 & - & - \\
\hline CV $(\%)$ & 17.32 & 4.30 & - & -
\end{tabular}

Note. $\overline{C V}$ : coefficient of variation. Averages followed by the same letter in the column do not differ statistically from each other by the Tukey test at the level of $5 \%$.

The germination of $C$. orbiculare conidia was suppressed by $75.00 \%$ when they were in contact with $R$. glutinis cell suspension, being more efficient than $Z$. hellenicus, which reduced germination by $56.32 \%$. This reduction may be related to the production of inhibitory compounds. Sansone et al. (2005) attributed the production of 
rodotorulic acid to the ability to reduce the germination of Botrytis cinerea spores. In the same way, Sipiczki (2006) attributed to rodotorulic acid the ability of $R$. glutinis to reduce the conidia germination of Penicillium expansum and B. cinerea.

On the other hand, yeast filtrates did not significantly interfere in the conidia germination (Table 2), Z. hellenicus significantly reduced germination by $11.41 \%$ while the yeasts $S$. cerevisiae, C. albicans and P. guilliermondii, did not reduce germination.

Considering the effective reduction of germination by cell suspension, but not being expressive with culture filtrate, it can be inferred that it is rodotorulic acid or another compound that interferes with germination, its synthesis is only stimulated in the presence of the competitor, in this case, C. orbiculare, making the use of microorganism itself more interesting than its filtrate as an alternative product.

Thus, it is possible to affirm that those yeasts that presented potential for reduction in mycelial growth by the production of volatile and non-volatile antimicrobial compounds also interfering in the germination of $C$. orbiculare conidia can be considered as suitable for use in biological control.

\subsection{Effect of Yeasts on the Protection of Cucumber Plants From Anthracnose}

Cotyledons treated with cell suspension from yeasts $Z$. hellenicus, $R$. glutinis and $S$. cerevisiae reduced the severity by $52.5,50.0$ and $42.5 \%$, respectively. However, in cotyledons without treatment, there was no difference (Figure 1). Since there is no significant difference in untreated cotyledons, it is possible to state that there was no systemic resistance induction in the plant, that is, yeasts applied to cotyledons did not activate defense mechanisms in a systemic way, therefore, they did not send signals to the cotyledon without treatment, showing that these yeasts act basically through direct biological control against the pathogen.

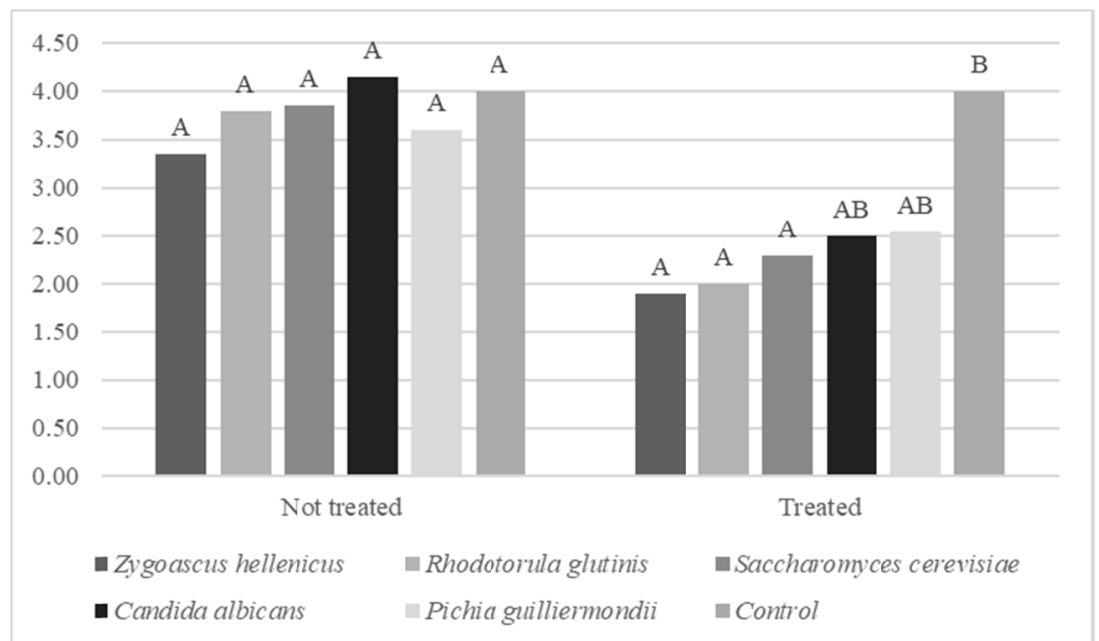

Figure 1. Severity of anthracnose caused by Colletotrichum orbiculare in cucumber cotyledons treated or not with yeast cell suspension

Note. Averages followed by the same letter do not differ statistically from each other by the Tukey test at the level of $5 \%$.

Studies carried out using the yeast $R$. glutinis reported significant results, such as the effectiveness of this yeast in controlling $B$. cinerea and $P$. expansum in apple fruits, where the results showed that the higher the concentrations of the antagonist, the lower the incidence of diseases (Zhang et al., 2009) and reduction of the fungus $B$. cinerea that causes gray mold in strawberry culture, when the fruits were stored at a temperature of 4 ${ }^{\circ} \mathrm{C}$, the reduction in the incidence of the disease was approximately $80 \%$ (Zhang et al., 2010).

Among treatments based on the use of antagonists, Silva et al. (2014) demonstrated that $R$. glutinis revealed significant results in relation to the control of soft rot of peppers, reducing the severity of the disease by $82.55 \%$, indicating that it is a possible alternative in the post-harvest management of this disease.

In evaluating the effects of $S$. cerevisiae on phytopathogens and on the manifestation of symptoms in different plant-pathogen interactions, under field conditions, some researchers showed results in which S. cerevisiae when 
applied weekly, reduced the speed of disease progression, in magnitude similar to the treatment with fungicide, causing an increase in productivity, generating data similar to the treatment with fungicide (Piccinin et al., 2005).

Zanardo et al. (2010), in studies on the resistance of cucumber seedlings to $C$. orbiculare induced by fractions of $S$. cerevisiae extract concluded that this yeast contains fractions inducing resistance to this disease, where cotyledons treated with crude extracts of this yeast autoclaved by 4 or $10 \mathrm{~h}$ showed a significant reduction in the severity of the disease, with 86.0 and $82.2 \%$, respectively.

\section{Conclusion}

The use of filtrate for testing non-volatile compounds stimulated the growth and sporulation of the pathogen in vitro.

Among all treatments, the yeast $R$. glutinis has the ability to reduce the growth of $C$. orbiculate both in vitro and in vivo under greenhouse conditions.

The yeasts used did not have the capacity to induce systemic resistance in the plant under greenhouse conditions.

For local protection, the yeasts $Z$. hellenicus, R. glutinis and S. cerevisiae proved to be efficient in reducing the disease caused by $C$. orbiculare under greenhouse conditions.

\section{Acknowledgements}

The authors would like to thank the Coordination for the Improvement of Higher Education Personnel (CAPES) and the State University of Western Paraná for their support in the development of the research.

\section{References}

Alfenas, A. C., Ferreira, F. A., Mafia, R. G., \& Gonçalves, R. C. (2016). Isolamento de fungos fitopatogênicos. In A. C. Alfenas \& R. G. Mafia (Eds.), Métodos em Fitopatologia (2nd ed.). Viçosa, Editora UFV.

Antoniolli, L. R., Silva, G. A., Alves, S. A. M., \& Moro, L. (2011). Controle alternativo de podridões pós-colheita de framboesas. Pesquisa Agropecuária Brasileira, 46, 979-984. https://doi.org/10.1590/S0100204X2011000900002

FAO (Food and Agriculture Organization of the United Nations). (2018). Retrieved May 14, 2020, from http://www.fao.org/faostat/en/\#data/QC

Ferreira, D. F. (2011). Sisvar: A computer statistical analysis system. Ciência e Agrotecnologia, 35, 1582-1589. https://doi.org/10.1590/S1413-70542011000600001

Fialho, M. B., Toffano, L., Pedroso, M. P., Augusto, F., \& Pascholati, S. F. (2010). Volatile organic compounds produced by Saccharomyces cerevisiae inhibit the in vitro development of Guignardia citricarpa, the causal agent of citrus black spot. World Journal of Microbiology and Biotechnology, 26, 925-932. https://doi.org/ 10.1007/s11274-009-0255-4

Filgueira, F. A. R. (2008). Novo manual de olericultura: Agrotecnologia moderna na produção $e$ comercialização de hortaliças (pp. 335-341). Viçosa, MG: Editora UFV.

França, G. S., Costa-Carvalho, R. R., Neves, R. P., Araujo, E. R., \& Laranjeira, D. (2015). Controle pós-colheita da antracnose do pimentão pela levedura Rhodotorula glutinis. Bioscience Journal, 31. https://doi.org/ 10.14393/BJ-v31n2a2015-22387

Kupper, K. C., Cervantes, A. L. L., Klein, M. N., \& Silva, A. C. (2013). Avaliação de microrganismos antagônicos, Saccharomyces cerevisiae e Bacillus subtilis para o controle de Penicillium digitatum. Revista Brasileira de Fruticultura, 35, 425-436. https://doi.org/10.1590/S0100-29452013000200011

Mari, M., Martini, C., Guidarelli, M., \& Neri, F., (2012). Postharvest biocontrol of Monilinia laxa, Monilinia fructicola and Monilinia fructigena on stone fruit by two Aureobasidium pullulans strains. Biological Control, 60, 132-140. https://doi.org/10.1016/j.biocontrol.2011.10.013

Piccinin, E., Di Piero, R. M., \& Pascholati, S. F. (2005). Efeito de Saccharomyces cerevisiae na produtividade de sorgo e na severidade de doenças foliares no campo. Fitopatologia Brasileira, 30, 5-9. https://doi.org/ $10.1590 / \mathrm{S} 0100-41582005000100001$

Sansone, G., Rezza, I., Calvente, V., Benuzzi, D., \& Tosetti, M. I. S. (2005). Control of Botrytis cinerea strains resistant to iprodione in apple with rhodotorulic acid and yeasts. Postharvest Biology and Technology, 35, 245-251. https://doi.org/10.1016/j.postharvbio.2004.09.005 
Schwan-Estrada, K. R. F., Stangarlin, J. R., \& Cruz M. E. S. (2003). Uso de plantas medicinais no controle de doenças de plantas. Fitopatologia Brasileira, 28, 554-556.

Shaner, G., \& Finney, R. E. (1977). The effect of nitrogen fertilization on the expression of slow-mildewing resistance in Knox wheat. Phytopathology, 67, 1051-1056. https://doi.org/10.1094/Phyto-67-1051

Silva, M. S., Carvalho, F. C. Q., Silva, J. R., Lins, S. R. O., \& Oliveira, S. M. A. (2014). Uso de antagonistas e produtos alternativos no manejo pós-colheita de podridão mole em pimentão. Revista Ciência Agronômica, 45, 718-725. https://doi.org/10.1590/S1806-66902014000400009

Sipiczki, M. (2006). Metschnikowia strains isolated from botrytized grapes antagonize fungal and bacterial growth by iron depletion. Applied and Environmental Microbiology, 72, 6716-6724. https://doi.org/10.1128/ AEM.01275-06

Trybom, J. (2010). Effect of seeding rate and seed treatment on soybean performance. Field Facts, 8, 1-3. Retrieved from http://cardycropsolutions.com/uploads/planting_effectofseedingrateandseedtreatmentonsoy beanperformance.pdf

Vale, F. X. R., Fernandes Filho, E. I., \& Liberato, J. R. A. (2003). Software plant disease severity assessment. Proceedings of International Congress of Plant Pathology (p. 105). Christchurch: International Society for Plant Pathology.

Zanardo, N. M. T., Pascholati, S. F., \& Fialho, M. B. (2010). Resistência de plântulas de pepineiro a Colletotrichum lagenarium induzida por frações de extrato de Saccharomyces cerevisiae. Pesquisa Agropecuária Brasileira, 44, 1499-1503. https://doi.org/10.1590/S0100-204X2009001100018

Zhang, H., Ma, L., Jiang, S., Lin, H., Zhang, X., Ge, L., \& Xu, Z. (2010). Enhancement of biocontrol efficacy of Rhodotorula glutinis by salicylic acid against gray mold spoilage of strawberries. International Journal of Food Microbiology, 141, 122-125. https://doi.org/10.1016/j.ijfoodmicro.2010.04.022

Zhang, H., Wang, L., Ma, L., Dong, Y., Jiang, S., Xu, B., \& Zhang, X. (2009). Biocontrol of major postharvest pathogens on apple using Rhodotorula glutinis and its effects on postharvest quality parameters. Biological Control, 48, 79-83. https://doi.org/10.1016/j.biocontrol.2008.09.004

\section{Copyrights}

Copyright for this article is retained by the author(s), with first publication rights granted to the journal.

This is an open-access article distributed under the terms and conditions of the Creative Commons Attribution license (http://creativecommons.org/licenses/by/4.0/). 